\title{
IDENTIFICATION AND IMPACT ANALYSIS OF INVASIVE Species: A CASE STUdy In The MONGLA Sea PorT AREA Of BAgERHAT District OF BANGLADESH
}

\author{
Md. Nurul Amin ${ }^{1}$, Mohd. Yousuf $\mathrm{Ali}^{2}$ and Md. Salequzzaman ${ }^{3}$ \\ ${ }^{1}$ Environmental Science Discipline, Khulna University, Khulna 9208, Bangladesh. \\ ${ }^{2}$ Fisheries and Marine Resource Technology Discipline, Khulna University, Khulna 9208, \\ Bangladesh. \\ Environmental Science Discipline, Khulna University, Khulna 9208, Bangladesh. \\ Email: nurulamin_35@yahoo.com, yousufku@gmail.com and salek_uz@yahoo.com
}

\begin{abstract}
Manipulation through invasion is a major problem in most of the port areas in recent world. Mongla is an important sea port that has accomplished the activities like import and export of various goods inside and outside Bangladesh. The process not only involves the moving of goods, it also carries the invasive species purposely or accidentally which invading to the new location of the Mongla port area through exploration and colonization with varieties diversity and scale. The paper identifies the invasive species and analyses the causes and ways of invasion in the coastal waters with possible impacts of invasion in the Mongla Port area. To achieve the objectives of the research, different aquatic species were collected by random sampling from the confluence of the River Passur Mongla port and the adjacent area around the Sundarbans from September 2006 to April 2007. The fishermen and local communities including indigenous people were interviewed to explore the invasion situation. The research reveals that ballast water of cargo ships is one of the means of invasion of the coastal waters of Mongla Port. Aquaculture is another reason of invasion due to introduction of many exotic fishes and shrimp species such as Pangus (Pangasius sutchi ), African Magur (Clarias gariepinus), Tilapia (Tilapia mossambica) and Nilotica (Oreochromis niloticus) etc. that have the active roles for altering the aquatic ecosystem of Mongla Port. Finally, the research also finds out some possible environmental impacts caused by those invasive species.
\end{abstract}

Key words: Invasive species, Aquaculture, Indigenous species, Aquatic ecosystem, Ballast water

\section{Introduction}

Invasive species, whether called nonnative, alien, exotic, or non indigenous or introduced species are those life forms that have evolved elsewhere and been purposely or accidentally moved to a new location [1]. Some have invaded habitats by themselves (e.g., migrating wildlife, plants, and animals rafting on floating debris); however, human exploration, colonization, and commercial trade have dramatically increased the diversity, scale, and impact of the invasions. Invasion of exotic species takes place in different types of ecosystems where as this concentrates on coastal aquatic invasive species, which draws the most alleged significance of the day. A major part of the aquatic invasive species is introduced by human activities. For example, the aquarium trade contributes to large number of aquatic species being accidentally or intentionally released into waterways. Aquaculture has also increased the spread of fish and other aquatic species and associated diseases. Thousands of species of marine organisms were and are moved around the world on ship bottoms, and hundreds more have been moved globally by the wholesale transfer of edible oysters for replanting. It is estimated that more than 10,000 marine species each day hitch rides around the globe in the ballast water of cargo ships [1]. Flooding can also transport nonnative aquatic and marsh species to new regions.

The invasive species spread quickly and easily in the new environment, as they get no enemy there. In their native habitats, these species are often harmless. However, when they enter new environment, for example water where natural controls are absent, they may out-compete native plants and animals. They can alter and degrade habitats and deplete food supplies, posing threats not only to the environment, but also to the economy, recreation and human health. For example, 
native amphibian and reptile populations worldwide are under threat from exotic invasive species of plants and animals, including other reptiles and amphibians [1].

Due to the multifaceted and incremental adverse impacts of invasive species, many relevant scientists revealed different aspects of invasive species including their causes of invasion, detrimental effects and the management options. According to the research report of Department of fisheries and forest some of the species of fishes and plants were introduced in Bangladesh. The most disastrous invasive fishes have predatory habit as well as extremely high fecundity and growth rate, and are able to breed naturally [2]. For this reasons some introduced species were prescribed only for restricted cultivation in closed ponds but nobody succeeded to maintain in that way due to flood. This caused 54 indigenous fishes to become threatened [3] within very short time. However, one of the true pictures of invasion is well known to us i.e. the outcome of water hyacinth invasion in all over the country's water body. But these are deliberate introduction of species, but invasion also come about by commercial trade related shipping activity in the port area. Mongla port is such an area that has all these criteria. So the risk of invasive species introduction and adverse impact outcome is likely to be much more prominent in Mongla port area. No scientific works have been done yet to explore this fact in this highly productive coastal region. Some anecdotal information supports these facts very strongly. Considering the scenario of USA and some other parts of Europe, the invasive species are being suspected as hidden slayers to the bio-diversity and livelihood of the coastal regions in many parts of the world including Bangladesh. At present the impact analysis on the invasive species in the aquatic environment in the Mongla sea port proves enormous value.

\section{Materials and Method \\ 2.1 Study area}

The study area lies $300 \mathrm{~km}$ Southwest of Dhaka, Bangladesh on the coastal plain at the apex of the Bay of Bengal. The area lies between $21^{\circ} 30^{\prime}$ and $23^{\circ} 15^{\prime}$ North and $89^{\circ}$ $00^{\prime}$ and $90^{\circ} 00^{\prime}$ east. It is at the side of the world's continuous mangrove forest [4]. The Mongla Port in the Pussur River is situated in the Southwest region of Bangladesh. The southwest area is bounded by the three major rivers (the Ganges, the Padma and the Lower Meghna), in the west by the Indian border and in the south is the Bay of Bengal [5].

\subsection{Selection of the Study design}

The type of study was Exploratory or formulative research. The main purpose of such research was to formulate a problem for more precise investigation or of developing the working hypothesis from an operational point of view. The major emphasis in such studies was on the discovery of ideas and insights.

\subsection{Sampling and Data collection}

The material sample was biological sample. The biological sample was range from plankton to higher vertebrates. Plankton and microscopic invertebrate samples were collected by using plankton net (mesh size $9 \mu \mathrm{m})$. In addition, the sample of vertebrates was collected through the fishermen working in the project area. Through proper preservation facilities (Lugol's solution and Borax buffered formalin), the plankton sample was analyzed in the laboratory of Environmental Science Discipline of Khulna University, Bangladesh.

The information about the in coming and out going ships of the Mongla port was collected from the Bangladesh Shipping Agent Association and harbor department of Mongla port authority. After identification of some invasive species, a survey was conducted by showing the photograph of those particular species and other recognized invasive species among the fishermen and local community peoples of the vicinity who were dependent on the aquatic resources of the study area. This survey would also reveal the clue of introduction of some invasive species to this area.

\subsection{Data analysis}

The information on species composition of the study area was obtained from secondary data. This information was reviewed by comparing primary data and a final database of native and invasive species is prepared based on this comparison. Microscopic planktons and invertebrates were identified by laboratory analysis under a light microscope by using Sedwick- Rafter cell. For the identification of the higher vertebrate, 
sessile species and fishes, the harvesting tools and different places of the relevant river was visited. The identification of the species is followed by standard classification method such as zoological classification method [6]. The occurrence of ship movement in and around the Mongla port area was analyzed by using interpretation of the same occurrence in other port areas around the world [7, 8, 9, 10, 11]. And to find out the information about the impact of invasive species in this area is compared with the similar occurrence of the same species in other areas.

\section{Results and Discussion}

3.1 Aquatic species in the Mongla port area

In the study area the existing brackish water habitats provide shelter, feeding and spawning grounds for different types of fish species. In fact, these habitats were under great threat due to the selective monoculture of Catfish that were identified as exotic or invasive species for Bangladesh [2]. During the field survey from September 2006 to April 2007, it was found that almost every fishermen of the Mongla port were catching these species time to time. Natural fishes were rare in this part and there was very little scope for other native fish species to adapt in such type of altered habitat due to prawn culture practices. Therefore, habitat fragmentation was enormous in research area that hampers the life cycle of the local aquatic organisms e.g. breeding behavior of the organisms. Rivers, canals and creeks of the Sundarbans supports varieties of brackish water aquatic organisms including different fish species. Indiscriminate fishing inside the
Sundarbans has virtually left no places for such type of fish species to spawn.

3.1.1 Plankton and other microscopic invertebrates

As no plankton species composition was found for the Mongla port area by the secondary literature survey, data merging with the research data was not possible. Therefore, only the Plankton and other microscopic invertebrates species found by the mentioned research process are shown in Table 1.

\subsubsection{Other Aquatic species}

The fish and other aquatic faunal sample collected from the fishermen and indigenous person was identified by standard zoological classification method [6]. Therefore, it was found that most of the above species of fish are of deformed size and shape. Those deformed shape of the aquatic organism might give the evidence that they might be altered by the influence of changed environment of the Mongla Port water. However, the fish and other species found in the port area are listed in Table 2 and Table 3.

\subsection{The causes of invasion in Mongla port}

Analyzing the causes and mechanisms of biological invasions, different approaches have been followed in the past. One of the most common approaches was the search for certain attributes, which make species invasive. Another approach was to look for abiotic or biotic conditions making a site or a community resistant to invasions. A third approach was to consider the possibilities for an organism to get transported as being crucial for the process of an invasion. In this context, the factors responsible for potential causes of invasion in Mongla port were:

Table 1 Phytoplankton and Zooplankton species in the Mongla port area.

\begin{tabular}{|c|c|c|c|c|}
\hline \multicolumn{2}{|l|}{ Phytoplankton } & \multicolumn{3}{|c|}{ Zooplankton } \\
\hline Class & Genus & Phylum & Class & Genus \\
\hline Chlorophyceae & $\begin{array}{l}\text { Closterium } \\
\text { Hydrodictyon } \\
\text { Chlorella }\end{array}$ & & & $\begin{array}{l}\text { Merocyclops } \\
\text { Mesocyclops } \\
\text { Cyclops }\end{array}$ \\
\hline Cyanophyceae & $\begin{array}{l}\text { Lyngbya } \\
\text { Oscillatoria } \\
\text { Schizothrix } \\
\text { Calothrix } \\
\text { Spriulina } \\
\text { Microcolens }\end{array}$ & 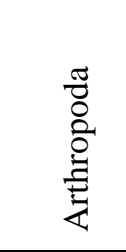 & 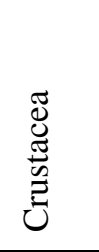 & $\begin{array}{l}\text { Diaptomus } \\
\text { Bosmina } \\
\text { Diaphasomqa } \\
\text { Praunus } \\
\text { Mysidella } \\
\text { Epinebalia }\end{array}$ \\
\hline
\end{tabular}




\begin{tabular}{||l|l|l|l|l||}
\hline \hline & $\begin{array}{l}\text { Gyrsigma } \\
\text { Navicula } \\
\text { Baillariophyceae }\end{array}$ & & & $\begin{array}{l}\text { Tigriospus } \\
\text { Oxyurostylis } \\
\text { Coscinodiscus } \\
\text { Coscinatas }\end{array}$ \\
\hline
\end{tabular}

Table 2 The Molluscan fauna found in Mongla port area

\begin{tabular}{||l|l|l||}
\hline \hline Phylum & Local Name & Scientific Name \\
\hline \multirow{4}{*}{ Mollusca } & \multirow{4}{*}{ Shamuk } & Narita lineata \\
\cline { 3 - 3 } & & Turbo (Lunella) cinereus \\
\cline { 2 - 3 } & $\begin{array}{l}\text { Zebra shamuk } \\
\text { (Invasive) }\end{array}$ & $\begin{array}{l}\text { Zebra Dreissena } \\
\text { polymorpha } \quad[1] .\end{array}$ \\
\hline
\end{tabular}

3.2.1 Shipping- ballast water and fouling organism

The recent research suggests that vessels are the primary type of vector that transports marine life to the port at an unprecedented rate. And these vessels could carry living aquatic organisms from fresh, brackish, or marine water, across and between oceans, or along coastlines, in a variety of ways like ballast tanks and others. Therefore, an arriving vessel may be a virtual "floating biological island," with hundreds of species living both on and in the ship [7, 8, 9, 10, 11]. However, from the last five years data it is found that more than 350 0r 400 (Annual) commercial clinker, container, cargo-carrying vessels and hundreds of thousands of recreational vessels ply in the Pussur River (Fig. 1).

According to the present investigation the ballast water discharged in Mongla port was not regulated by the authority or not regulated by the international protocols or local laws. Therefore, about each and every ship was discharging its ballast water in port water body when they need. In this context, from the above reference we can easily mention that the Mongla port area, which is one of the important coastal parts of Bangladesh, is under great threat of invasion due to shipping related activity.

3. 2. 2 Water diversions for aquaculture and fisheries activities

Water diversion for the shrimp practices was very frequent in the Mongla port area, which could be termed as a significant cause of introduction of invasive species in the river water body. The main water diversion practices occur at the time of first monsoon when the water level and the flow velocity of Pussur River near Mongla port are very high. So, the transportation of new invader to the Pussur River of the Mongla port area by the water diversion canal becomes very easier. The Figure 2 illustrates a general pathway for water diversion in the study area. Water diverted for agriculture or shrimp culture purposes increase salinities [2].

Table 3 The fish and shrimp species found in catches of different spot of the Pussur River

\begin{tabular}{|c|c|c|c|}
\hline Species & Local name & Scientific name & Remarks \\
\hline \multirow{8}{*}{$\begin{array}{l}\text { 离 } \\
\text { 乙 }\end{array}$} & Bagda pona & Penaeus monodon & \\
\hline & Golda pona & Macrobrachium rosenberii & \\
\hline & Paisha & Liza persia & \\
\hline & Taposhi & Polynemus paradisous & \\
\hline & Vatki & Lates calcarifer & \\
\hline & Datina & Sparus datina & \\
\hline & Vhola & Barilius Bole & \\
\hline & Illish & Hilsa ilisha & \\
\hline \multirow{2}{*}{ 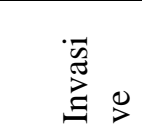 } & Tilapia & Tilapia mossambica & \multirow{2}{*}{$\begin{array}{c}\text { These fish are } \\
\text { identified as } \\
\text { invasive by }\end{array}$} \\
\hline & Nilotica & Oreochromis niloticus & \\
\hline
\end{tabular}




\begin{tabular}{||l|l|l||c||}
\hline \hline & Pangus & Pangasius sutchi & Rahman,1997 \\
\cline { 2 - 3 } & African Magur & Clarias gariepinus & \\
\hline
\end{tabular}

alter both donor and recipient environments,

The major forces driving change in coastal creating new opportunities for transport and biodiversity_habitat alteration; chemical pollution; eutrophication or over enrichment; climate change; fisheries impacts; and introductions. Therefore, this phenomena is a significant topic of concern for allover the introductions themselves [13]—constantly

coastal area of Bangladesh

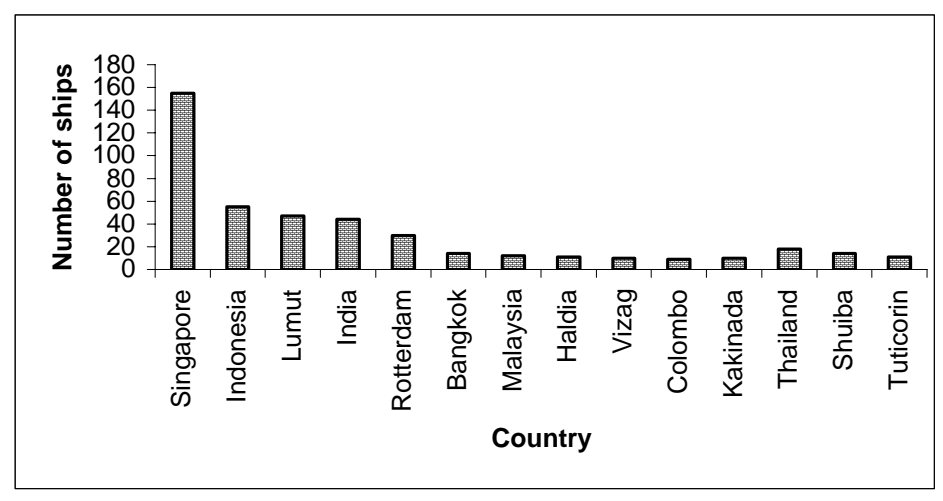

Fig. 1 Frequency of incoming Ships in Mongla port from different parts of the world from year 2000 to 2004 [12]

On the other hand, the dispersal of invasive species occurs through a wide range of fisheries activities. The fisheries activity was one of the prominent commotions to the coastal area especially to the Mongla port of Bangladesh. These activities fall into two broad categories of intentional releases -legal or illegal-and accidental releases. An unknown number-in terms of both species and individuals — of living marine organisms are deliberately transported around the world on a daily basis. In this aspect, the culturing of Catfish like Pangus (Pangasius sutchi) African Magur (Clarias gariepinus) etc in the paddy field of the Mongla area's is a topic to consider with great awareness as it is unintentionally introducing in the river water body which was found during field survey.

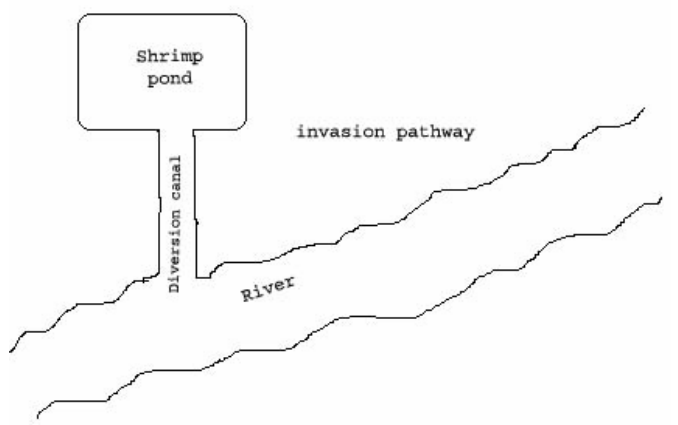

Fig. 2 Invasion pathway model for water diversion

\subsection{Ecological impact of aquatic invasive species}

The ecological and biodiversity consequence of the introduction of species is a long term phenomena. However, this initiative is to correlate the invented ecological impact with port area's invasion condition and to show it as an overall state for the coastal area of Bangladesh. So, this could be very much hard topic to consider. Therefore, the ecological impact of these species in this area on the basis of different references is shown in Figs. 3-4.

\section{Conclusion}

From the study, it is clear that the deliberated invasion is at a stage in the Mongla port area, which will definitely cause suffering for us in the day to come. In addition, this research also proved that some familiar causes of aquatic invasion were very much present in Mongla port and its adjacent area. Therefore, alike all the known adverse effects of the invasive plants and animal including fishes in all over country, introduction of invasive species and its impact in the Mongla port area will certainly add a new paradigm of troublemaker in the coastal area. Therefore, preventive measures are the essential prerequisite for the more ecologically sustainable management at the port area of Bangladesh. 


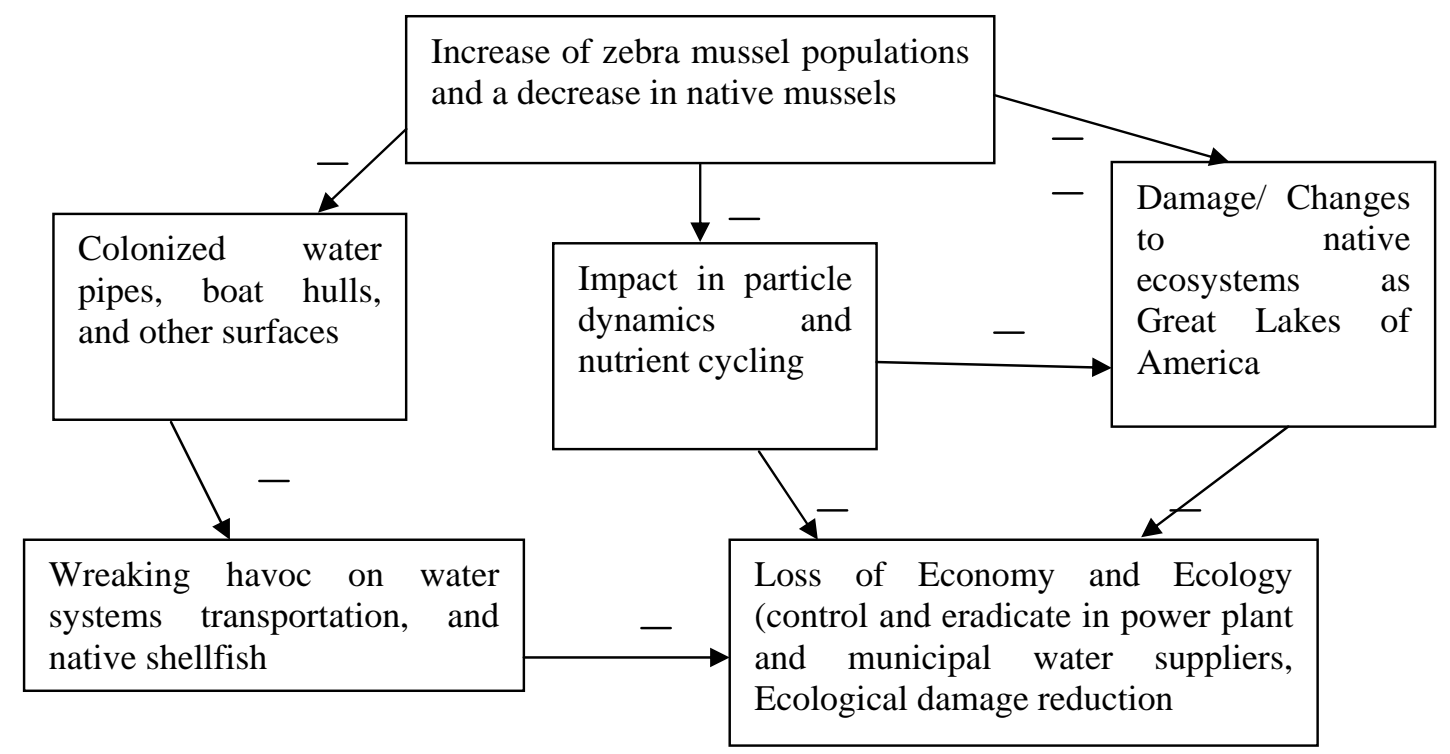

Fig. 3 Causal loop diagram of ecological impact of Zebra mussel in Mongla port area on the basis of [8]

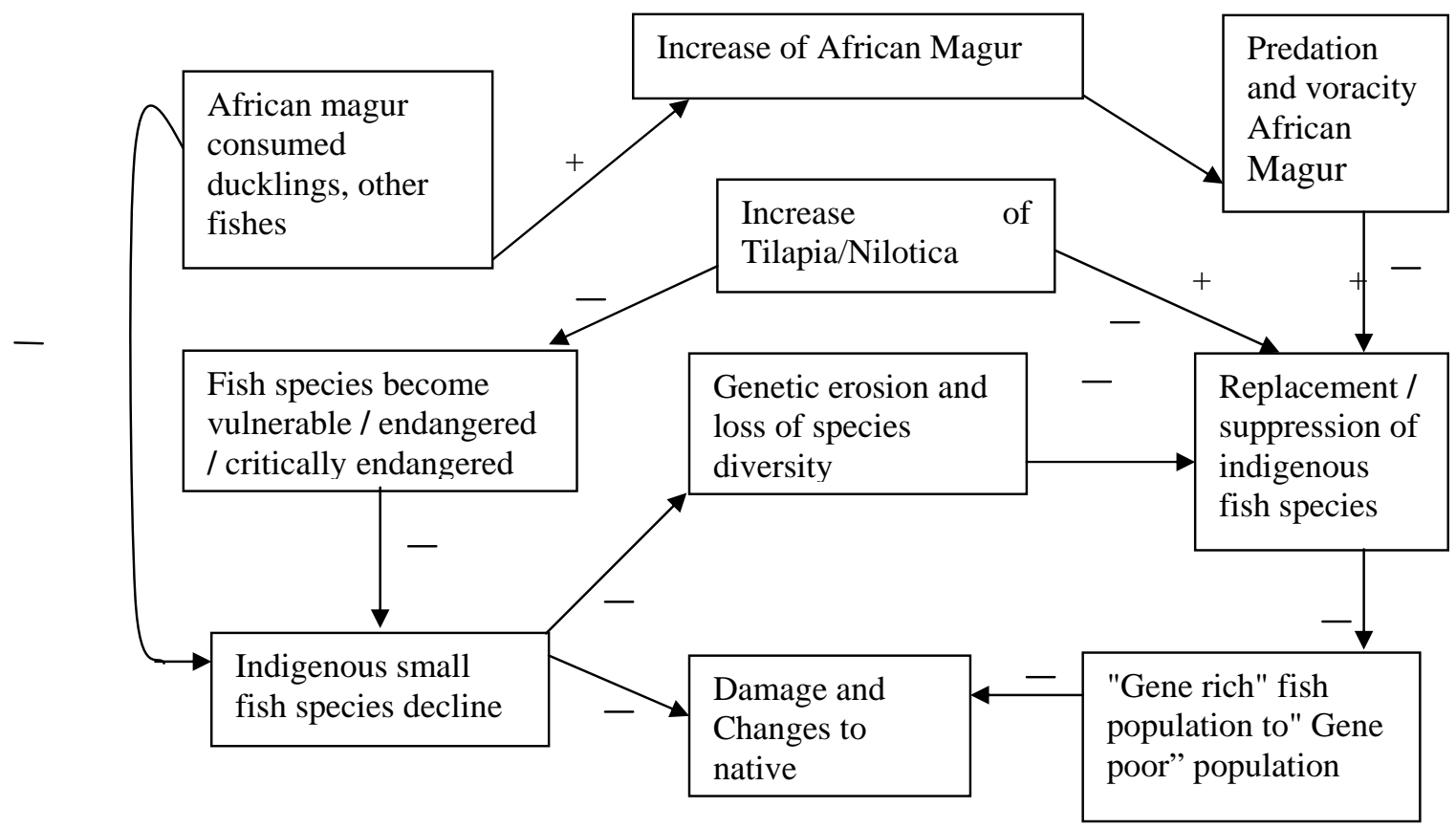

Fig. 4 Causal loop diagram of ecological impact of some fish population in Mongla port area on the basis of [2, 14]

\section{References}

[1] Ecological Society of America (ESA) Biotic Invasions: Causes, Epidemiology, Global Consequences and Control, National Academy press Washington, DC, 1998.http://www.esa.org/issue5.htm (Accessed on 14 may, 2005).

[2] A. K. A. Rahman, Fish Marketing in Bangladesh. In, Tsai, C. F.; Yousuf, M. A. (ed) Openwater
Fisheries of Bangladesh. BCAS/University Press Limited, 1997.

[3] IUCN Bangladesh, Red Book of Threatened Fishes of Bangladesh. IUCN- The World Conservation, 2000.

[4] C. Giri, and S. Shrestha, "Land cover mapping and monitoring from NOAA AVHRR data in Bangladesh”, International Journal of Remote sensing vol.17, No.14, 1996, pp. 2749-2759.

[5] D.R.P. Farleigh, Pussur River Study Phase I, Final Report, Port of Chalna Authority, 1981. 
[6] O. Banerjee, Zoological Classification Theory. Inidiana publishers, New Delhi, India, 1991, pp.10-31.

[7] J. T. Carlton, "Transoceanic and interoceanic dispersal of coastal marine organisms: the biology of ballast water", Oceanography and Marine Biology, an Annual Review, 1985, vol.23, pp.313371.

[8] J. T. Carlton, Dispersal mechanisms of the zebra mussel (Dreissena polymorpha). In, Nalepa, T. F.; D. Schloesser, W. (ed) Zebra Mussels: Biology, Impacts, and Control. CRC Press, Inc., Boca Raton, Florida, 1993, pp. 677-697.

[9] J. T. Carlton, and J. B. Geller, "Ecological roulette: The global transport of non-indigenous marine organisms", Science, vol.261, 1993, pp. 78-82.

[10] J. T. Carlton, and J. Hodder, "Biogeography and dispersal of coastal marine organisms: experimental studies on a replica of a 16th-century sailing vessel”, Marine Biology vol.121, 1995, pp.721-730.

[11] M. J. Wonham, J. T. Carlton, G.M. Ruiz, and L. D. Smith, "Fish and ships: relating dispersal frequency to success in biological invasions", Marine Biology vol.136, 2000, 1111-1121.

[12] Bangladesh Shipping Agent Association, Khulna (BSAA). Berth Allocation meeting, Mongla port Authority, Harbour and conservancy department, Mongla Port Authority, Mongla, Bagerhat Bangladesh. 2005. http:// www. Bsaakhulna.com.

[13] National Research Council. Understanding Marine Biodiversity. National Academy Press, Washington, D.C, 1995. pp.15-42

[14] M. Ameen 1999. Development of Guiding Principles for the Prevention of Impacts of Alien Species. In: The consultative workshop in advance of the 4th Meeting of SBSTTA to the CBD, organized by IUCN Bangladesh at Dhaka on 25 May 1999. 